\title{
下地コンクリートに拘束される仕上モルタルにおいて 乾燥収縮ひび割れが発生しやすい位置の予測 CRACK PREDICTION ANALYSIS FOR DRYING SHRINKAGE OF WET FINISHING PLASTERING MATERIALS ON THE EXTERNAL WALL
}

\author{
松 本 慎 也*，大久保 孝昭** \\ Shinya MATSUMOTO and Takaaki OHKUBO
}

\begin{abstract}
In this paper, it is shown that a crack prediction analysis for drying shrinkage of wet finishing plastering materials on the external wall. In this analysis, the drying shrinkage strain in the mortar is determined by proposal measurement procedure for the age. The internal stress in the finishing mortar is analyzed by finite element method based on the plane stress problem for the drying shrinkage strain derived from experimental measurement. We illustrate the method which predicts the crack generation point and time in finishing mortar. This present method is formulated by two-dimensional finite element method to apply the crack prediction for the opening on wall corners. The effectiveness of present method is verified by comparing the numerical results with the experimental tests. We investigate analytically the typical characteristics of the drying shrinkage of the external wall using wet finishing plastering material by numerical studies.
\end{abstract}

Keywords: Mortar, Restraint effect, Crack, Plane stress analysis, Finite element method モルタル，拘束効果，ひび割れ，平面応力解析，有限要素法

\section{1.はじめに}

左官モルタルは建築仕上げ材として木造や鉄筋コンクリート造な どの各種構造の外壁仕上げ工事に広く用いられている。また, タイ ル張り外壁や躯体の不陸調整を含む下地材料としても使用され，外 壁仕上げにおいて重要な材料であり，外部からの各種劣化要因から 躯体を保護し，建築物の美観と耐久性を保持する役割を果たす材料 である。しかし，左官モルタルなどの湿式仕上げ材は，材料特性上， 乾燥収縮に伴うひび割れが生じや寸い欠点を有しており，仕上げ材 のひび割れは，部位の耐久性低下に大きな影響を及ぼすため，有効 なひび割れ制御技術の確立が急務である。これまでに構造躯体であ る鉄筋コンクリート造建築物に対しては数多くの研究が行われてい る1)。また, 解析的な研究としては, 文献2)-5)などの研究が行われ ている。

本研究では，モルタル供試体の材齢にともなう体積変化量を実測 することで材料の自由収縮ひずみ特性を求め, そのひずみ量を用い た初期ひずみ問題を有限要素法によって解くことで, 仕上モルタル の乾燥収縮にともなう内部応力を解析し，仕上げ材に生じるひび割 れの生じやすい位置を予測する一手法を提案する。この成果は設計 段階において, 開口部の位置や形状, 伸縮調整目地の位置等を検討
する際に有効となる。また, 仕様の決定段階においては, ひび割れ の生じやすい位置におけるひび割れ制御（低収縮モルタルやメッシ ユの使用など）の効果的な実施の提案等にも役立つものと考えてい る。

本論文では，まず，実験に供した仕上モルタルの乾燥収縮量を計 測する。また，下地材の拘束力を受けながら収縮する仕上モルタル の収縮量を計測する試験を行い, これらの結果から下地材の拘束効 果を定量的に評価するための解析法を定式化し，仕上モルタルの材 齢にともないモルタル内部に生じる応力を解析する。本手法は，平 面的な広がりのある壁面の開口部周辺などの部位に対しても統一的 にひび割れ予測を行うことができるように，定式化には，2 次元有 限要素法を用いており, 伸縮調整目地の位置の検討等に活用するこ とが可能である。なお，本研究は，仕上モルタルにおいてひび割れ が発生するか否かの判定をするのではなく，ひび割れが発生しやす い位置と方向を抽出することを目的とした応力分布を解析対象とし ている。従って, クリープや応力緩和の影響は本論文では考慮して いない。また, 実際の壁では左官仕上げの塗り厚はばらつくことが 予測されるが，塗り厚と拘束率の検討は非常に複雑なために，この ようなモルタルの塗り厚は今後の課題とする。
$*$ 広島大学大学院工学研究科 助教 $\cdot$ 博士 $($ 工学 $)$

** 広島大学大学院工学研究科 教授. 工博
Assistant Prof., Graduate School of Engineering, Hiroshima University, Dr. Eng.

Prof., Graduate School of Engineering, Hiroshima University, Dr. Eng. 


\section{2. コンクリート下地に拘束される仕上モルタルの収縮応カ解析}

\section{1 解析法の概要}

本解析法は，モルタルの収縮変形を厚さ方向の代表平面において 評価するものとし, 下地材による拘束力は, 要素節点と下地材とを 結ぶバネ要素を用いて評価することで，収縮によってモルタル内部 に生じる応力を求める解析法である (図 1参照)。実際には, 図 1 に 示すようにモルタルの収縮変形には勾配が生じている。本論文では 解析手法を簡便化するために，モルタルが一様に収縮しようとする ものと仮定した解析手法を提案しており，モルタル栾形の入力デー 夕は，後述の図 5 に示すようにモルタル厚みの中央で計測した值を 用いている。すなわち本解析では仕上モルタル層の厚さ方向に対し 分布する変形勾配を，モルタル厚の中央位置で代表させて扱うもの とする。よって，仕上モルタルの変形勾配に影響するモルタルの厚 み, 左官後の材齢および乾燥速度などは, 今後実験データを蓄積し てモルタルの変形の入力データを整備する必要がある。

このとき，下地材の拘束力の違いは，各要素境界の節点における 離散的なバネ要素の剛性によって評価する。したがって，下地材の バネ剛性を適切に評価するためには，ある程度細かな要素分割が必 要となるため, 本解析では, 高次の面内要素として提案されている Wilson-Taylor の非適合四辺形要素(6)面内変形要素に用いることと し(図 2参照)，十分な要素分割を行うこととした。

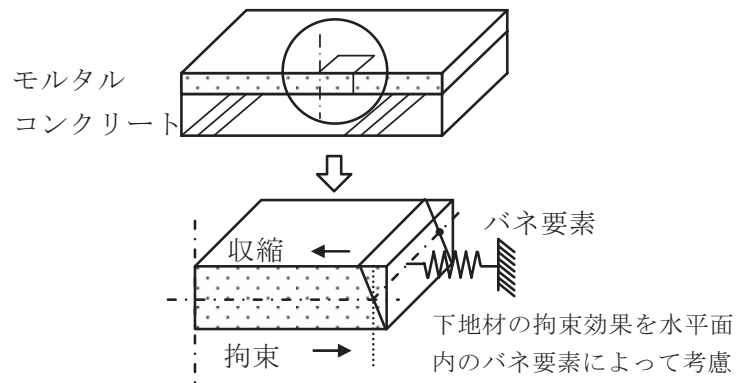

図 1 解析法の概念図

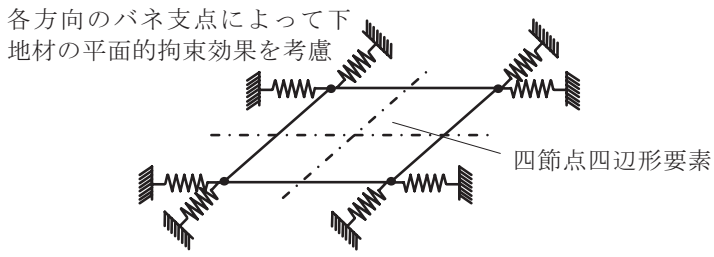

図 2

バネ支点による平面的拘束効果のモデル化

本解析法ではあらかじめ次に示す(1)から (3)の諸データを各モルタ ルの調合ごとに実験的に計測しておく必要がある。

(1) 仕上げ層のモルタル単体の 1 面乾燥状態における自由収縮ひ ずみ $\varepsilon_{0}$

(2)下地材の拘束効果を受ける仕上げ層のモルタルの拘束収縮 ひずみ

(3) 仕上げ層のモルタルの材齢に伴う弾性係数 $E$

このとき，(1)モルタルの自由収縮ひずみ $\varepsilon_{0}$ と(2)モルタルの拘束収 縮ひずみ $\varepsilon$ に関しては, モルタルの塗り厚ごとに求める必要がある。 これらの諸データは，後述する実験によって計測する。

\section{2 バネ要素による下地材の拘束の考慮}

図 3 に下地材の拘束効果を計測するための概要図を示す。

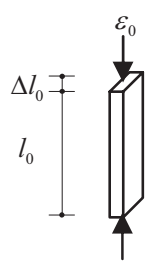

自由収縮ひずみ

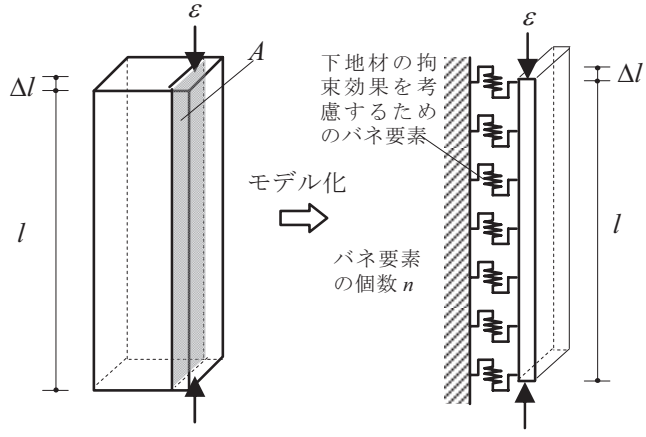

拘束収縮ひずみ
拘束効果のモデル化
図 3 下地材の拘束効果の計測に対する概要図

このとき, 拘束収縮ひずみ $\varepsilon$ は, 仕上げ層の自由収縮ひずみ $\varepsilon_{0}$ に, あるひずみ分布 $\varepsilon_{a}$ を加えた結果，最終的に適合するひずみの状態を 実現せねばならない。すなわち式で表記すると次式となる。

$$
\varepsilon=\varepsilon_{0}+\varepsilon_{a}
$$

(1)式より $\varepsilon_{a}$ は, 次式のように表される。

$$
\varepsilon_{a}=\varepsilon-\varepsilon_{0}
$$

このとき，仕上げ層に生じる応力（内部拘束応力）は，(2)式で表 されるひずみ $\varepsilon_{a}$ に対して生じるため, 仕上げ層のモルタルの弾性係 数を $E$ とすると, 内部拘束応力は次式によって表される。

$$
\sigma=E \varepsilon_{a}
$$

拘束収縮ひずみを計測した試験体における仕上げ層の全面積を $A$ 試験体全長を $l$ とすると，下地材のバネ剛性 $K$ は，収縮によって生 じる等価な収縮力と内力のつり合い関係より，(2)式で定義されるひ ずみ $\varepsilon_{a}$ の符号が逆転する形で，次式のように導かれる。

$$
K=\frac{E\left(\varepsilon_{0}-\varepsilon\right) A}{\varepsilon l}
$$

解析対象を有限要素でモデル化する際に要素ごとに仮定するバネ 剛性 $k_{i}$ は，バネを仮定する各節点における周辺要素の負担面積 $A_{i}$ を計算し，要素の総面積 $\sum^{n} A_{i}$ （ここに， $n$ は要素数）に対する重み として下地材のバネ剛性 $K$ にかけることで次式のように求めること ができる。

$$
k_{i}=\frac{A_{i}}{\sum A_{i}} K
$$

このとき，各支点の負担面積は，以下に示す座標法によって面積 計算を行うことができ，計算する四辺形要素の各節点座標を $\left(\begin{array}{ll}x_{j} & y_{j}\end{array}\right)$ としたとき, 四辺形要素の面積 $A_{i}$ は次式のように表される。

$$
\begin{gathered}
A_{i}=\frac{1}{2}\left|\sum_{j=1}^{n}\left(x_{j} y_{j+1}-x_{j+1} y_{j}\right)\right| \\
\text { ここに, }\left(\begin{array}{c}
x_{n+1} \\
y_{n+1}
\end{array}\right)=\left(\begin{array}{c}
x_{1} \\
y_{1}
\end{array}\right), \text { ただし, } n=4
\end{gathered}
$$

また，四角形の等分定理を用いて負担面積を計算する際の節点座 標を求め，(6)式の計算の座標值として用いる。 


\section{3 近似関数による材料特性値のモデル化}

本解析では，材齢に対するモルタルの自由収縮ひずみ $\varepsilon_{0}$, 拘束収 縮ひずみ $\varepsilon$, 弾性係数 $E$ の各特性值を材齢 $t$ の近似関数で表すこと とし，(7)式に示すような 3 つのパラメータを有する指数関数式で仮 定する。(7)式は自由収縮ひずみに対する近似式を示すが，他の特性 值（拘束収縮ひずみ, 弾性係数）についても, 同様に近関数で仮定 する。この 3 つのパラメータはそれぞれ， $a=$ 曲線の初期勾配， $b=$ 曲 線の漸近值, $c=$ 曲線の曲がり具合を意味するパラメータであり, 図 4に示すような曲線を意味する。

$$
\varepsilon_{0}(t)=\frac{a t}{\left(1+\left(\frac{a t}{b}\right)^{c}\right)^{\frac{1}{c}}}
$$

$$
\begin{aligned}
& \text { ここに, } \quad a: \text { 曲線の初期勾配 } \\
& \quad b: \text { 曲線の漸近值 } \\
& c: \text { 曲線の曲がり具合 }
\end{aligned}
$$

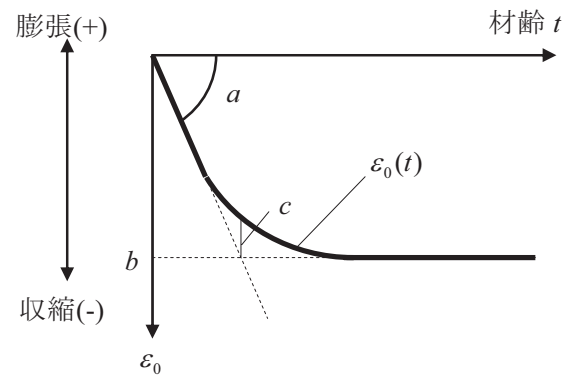

図 4 自由収縮ひずみの近似関数

これらの近似関数を用いて, 実験によって得られるモルタルの自 由収縮ひずみ $\varepsilon_{0}$, 拘束収縮ひずみ $\varepsilon$, 弾性係数 $E$ の各特性值をモデ ル化し，解析に用いる。

\section{3. 実験方法}

\section{1 下地材のバネ剛性 (拘束度)を求めるための実験法}

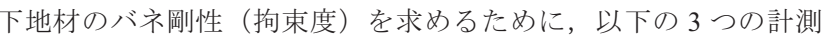
を行う。すなわち，(1)モルタルの自由収縮ひずみの計測，(2)モルタ ルの拘束収縮ひずみの計測, (3)モルタルのヤング係数の計測である。 これらの乾燥収縮に対するひずみを計測する際に, 試験体全体の反 りの影響が存在するが，本実験では，それらの影響は小さいものと し，その変形量まで含めた形で計測を行った。それぞれの詳細につ いては以下に述べる。

(1)モルタルの自由収縮ひずみの計測法

自由収縮ひずみの試験体の形状は, $40 \times 20 \times 160 \mathrm{~mm}$ であり, 図 5 • (1)に示す。試験体側面は，ろうでシーリングすることで，乾燥面を 1 面乾燥状態とした試験体を作成する。自由収縮ひずみの計測は, 材齢 1 日から開始し，91 日間（13 週間）行った。試験体は，温度 $20{ }^{\circ} \mathrm{C}$, 湿度 $60 \% \mathrm{Rh}$ の恒温恒湿室内で高感度変位計（東京測器社製 CDP-5）を用いて各計測ポイントにおける試験体の長さ変化を計測

し，各収縮量から収縮ひずみを求める。

(2)モルタルの拘束収縮ひずみの計測法

拘束収縮ひずみの試験体は, 乾燥収縮がある程度進行した後のコ
ンクリート（材齢 28 日）にモルタルを塗り厚 $20 \mathrm{~mm}$ で左官するこ とで，図 5・(2)のように作成する（コンクリートの寸法は $100 \times 100$ $\times 400 \mathrm{~mm})$ 。試験体側面は，ろうでシーリングし，乾燥面をモルタ ル仕上げ面の一面のみとした。拘束収縮ひずみの計測は材齢 1 日か ら開始し, 91 日間 (13 週間) 行った。試験体は, 温度 $20^{\circ} \mathrm{C}$, 湿度 $60 \% \mathrm{Rh}$ の恒温恒湿室内で高感度変位計（東京測器社製 CDP-5）を用 いて各計測ポイントにおける試験体の長さ変化を計測し, 各収縮量 から収縮ひずみを求める。このとき，変位の計測位置は前節で示し た解析モデルの仮定に合わせ，モルタル層の中央位置とする。実際 の試験体では，変位計の先端の形状に合わせたくぼみをつけたボル 卜を埋め込み，適切に接触するようにして，計測を行った。

(3)モルタルの弾性係数の計測法

各試験体に用いるモルタルにおいて直径 $\phi 50 \mathrm{~mm} \times$ 高さ $100 \mathrm{~mm}$ の 円柱状供試体を 3 体作成し，材齢 1 日，3 日，7 日，14日，28日， 91 日において，モルタルの圧縮試験を行い，その結果から，各材齢 における圧縮強度および弾性係数を求めた。これらの円柱状供試体 は, 脱型を材齢 1 日で行い, 力学試験を行う所定の材齢までは, モ ルタルの収縮ひずみの計測を行う試験体と同一の恒温恒湿室（温度 $20^{\circ} \mathrm{C}$, 湿度 $60 \% \mathrm{Rh}$ ）において気乾養生を行った。また，各材齢にお けるモルタルの引張強度を得るために, 同様に, 直径 $\phi 50 \mathrm{~mm} \times$ 高 さ $100 \mathrm{~mm}$ の円柱状供試体を 3 体作成し割裂引張試験も合わせて行 った。
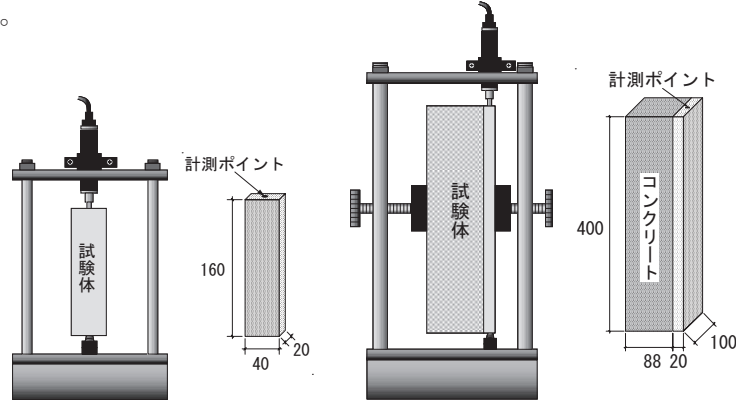

1) 自由収縮ひずみ

(2) 拘束収縮ひずみ

図 5 試験体形状とひずみの測定箇所

本実験では，表 1 に示す調合の普通モルタルを実験に用いた。こ のときモルタルには，エチレン酰酸ビニル系混和材料（EVA）を混 入したモルタルを用いた。また，拘束収縮試験体の下地材に用いた コンクリートの計画調合を表 2 に示す。

\begin{tabular}{|c|c|c|c|c|c|c|c|c|c|c|c|c|c|}
\hline \multirow{2}{*}{$\begin{array}{c}\text { 調合強 } \\
\left(\mathrm{N} / \mathrm{mm}^{2}\right)\end{array}$} & \multirow{2}{*}{$\begin{array}{c}\text { スランプ } \\
(\mathrm{cm})\end{array}$} & \multirow{2}{*}{$\begin{array}{l}\text { 空気量 } \\
\text { (\%) }\end{array}$} & \multirow{2}{*}{$\begin{array}{c}\text { 水セx } \\
\text { ト比 } \\
(\%)\end{array}$} & \multirow{2}{*}{$\begin{array}{c}\text { 粗骨材 } \\
\text { 最大 } \\
\text { 法 } \\
(\mathrm{m})\end{array}$} & \multirow{2}{*}{$\begin{array}{c}\text { 細骨材 } \\
\text { 率 } \\
(\%)\end{array}$} & \multirow{2}{*}{$\mid \begin{array}{c}\text { 単位水 } \\
\text { 量 } \\
\left(\mathrm{kg} / \mathrm{m}^{3}\right)\end{array}$} & \multicolumn{3}{|c|}{$\begin{array}{l}\text { 絶対容皘 } \\
\left(\ell / m^{3}\right)\end{array}$} & \multicolumn{3}{|c|}{$\begin{array}{c}\text { 質量 } \\
\left(\mathrm{kg} / \mathrm{m}^{3}\right)\end{array}$} & \\
\hline & & & & & & & $\begin{array}{l}セ \\
x \\
\dot{x} \\
\text { r }\end{array}$ & $\begin{array}{l}\text { 細 } \\
\text { 骨 } \\
\text { 材 }\end{array}$ & $\begin{array}{l}\text { 粗 } \\
\text { 骨 } \\
\text { 材 }\end{array}$ & $\begin{array}{l}セ \\
x \\
\dot{x} \\
\text { r }\end{array}$ & $\begin{array}{l}\text { 細 } \\
\text { 骨 } \\
\text { 到 }\end{array}$ & $\begin{array}{l}\text { 粗 } \\
\text { 骨 } \\
\text { 材 }\end{array}$ & \\
\hline 33.5 & 15 & 4.5 & 55 & 20 & 43 & 171 & 98 & 295 & 391 & 311 & 761 & 1032 & 3.1 \\
\hline
\end{tabular}

表 1 モルタルの調合表（質量比）

\begin{tabular}{|c|c|c|c|c|}
\hline $\begin{array}{c}\text { モルタルの } \\
\text { 種類 }\end{array}$ & セメント & $\begin{array}{c}\text { 砂 } \\
\text { (砕砂) }\end{array}$ & $\begin{array}{c}\text { 水 } \\
(\mathrm{W} / \mathrm{C})\end{array}$ & $\begin{array}{c}\text { 混和材料 } \\
(\mathrm{A} / \mathrm{C})\end{array}$ \\
\hline \hline 普通モルタル & 1 & 2.8 & $56 \%$ & $\mathrm{EVA}: 0.1$ \\
\hline
\end{tabular}

表 2 コンクリートの調合 


\section{2 解析精度を検証するための模擬試験体による実験法}

解析精度を検証するために, 開口部周辺を模擬した試験体 (以後, 模擬試験体と呼称）によって, 本解析法の検証を行った。試験体は, 厚さ $30 \mathrm{~mm}$ の既成コンクリート板 $(300 \mathrm{~mm} \times 300 \mathrm{~mm})$ に，普通モル タルを厚さ $20 \mathrm{~mm}$ で左官することで作成した。モルタルの調合は, 3.1 節に示した計測に用いたモルタルの調合と同一である（表 1 参 照)。試験体の形状は，モルタル部分の中央部に，図 6に示すような $100 \mathrm{~mm} \times 100 \mathrm{~mm}$ の開口部を有する $300 \mathrm{~mm} \times 300 \mathrm{~mm}$ のロの字型の平面 形状である。

この模擬試験体は, モルタル施工直後から, 温度 $20^{\circ} \mathrm{C}$, 湿度 $60 \%$ $\mathrm{Rh}$ の恒温恒湿で養生し，ひずみ計測も同一の条件下で 91 日間（13 週間）行った。このときひずみ計測は，3 軸ひずみゲージ（ゲージ 長 $20 \mathrm{~mm}$ ）を用いて，図 6に示す $\mathrm{A} \sim \mathrm{C}$ の 3 か所におけるひずみを 計測した。このときひずみの計測は，モルタルを施工した翌日（材 齢 1 日）から行った。
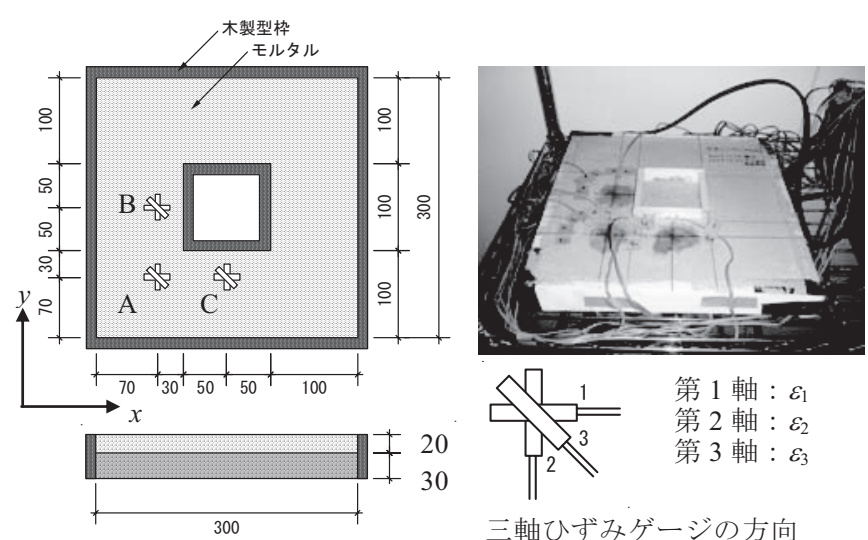

三軸ひずみゲージの方向

図 6 試験体形状とひずみの測定箇所

\section{4. 実験及び解析結果}

\section{1 実験によるバネ剛性の算定結果}

3.1 節で述べた実験手法（図 5参照）によって計測したモルタル の自由収縮ひずみとその近似式を図 7に示す。また同様に，モルタ ルの拘束収縮ひずみの実測結果とその近似式を図 8 に示す。

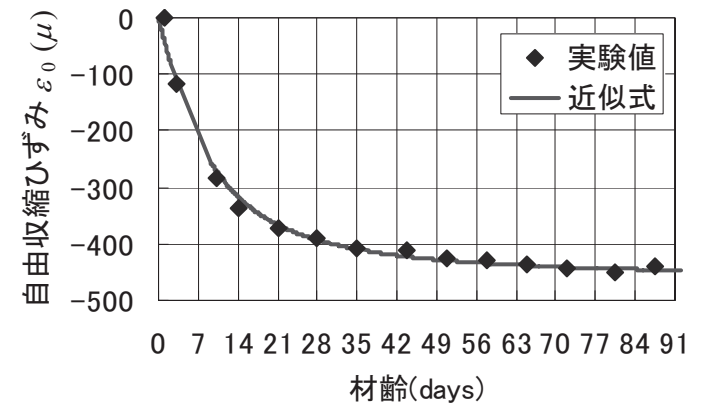

図 7 モルタルの自由収縮ひずみ

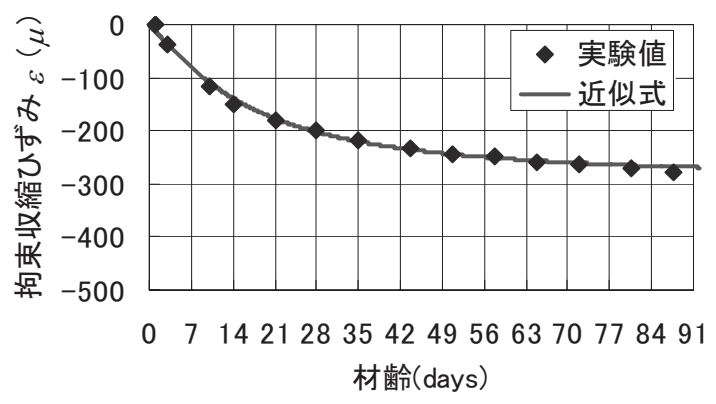

図 8 モルタルの拘束収縮ひずみ

また，モルタルの圧縮試験から求めた弾性係数（3 供試体の平均 值）の実験值とその近似式を図 9に示す。以上に示した実験結果に 対する近似式の各パラメータを表 3 にまとめる。

図 7〜図 9より，拘束収縮ひずみは 13 週間（91 日間）程度かけ て進行するのに対し, 弾性係数は概ね材齢 28 日程度で最終的な值と なる傾向にあることがわかる。

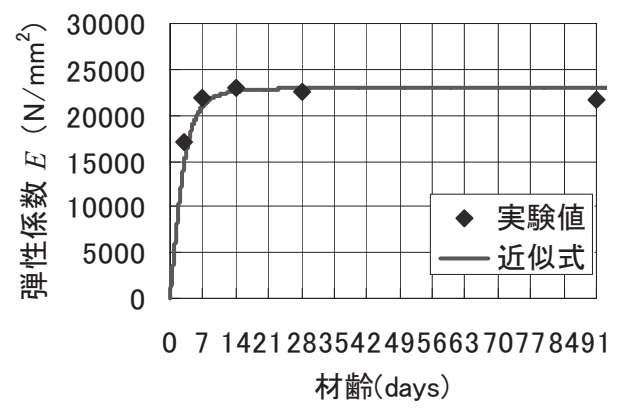

図 9 モルタルの弾性係数

表 3 近似式のパラメータ

\begin{tabular}{|c|c|c|}
\hline \multirow{2}{*}{$\begin{array}{c}\text { 自由収縮ひず } \\
\text { み }\end{array}$} & $\begin{array}{c}\text { パラメー } \\
\text { タ }\end{array}$ & 普通モルタル \\
\cline { 2 - 3 } & $a$ & $-4.6 \times 10^{-10}(1 / \mathrm{sec})$ \\
\cline { 2 - 3 } & $b$ & $-4.6 \times 10^{-4}$ \\
\hline $\begin{array}{c}\text { 拘束収縮ひず } \\
\text { み }\end{array}$ & $c$ & 1.5 \\
\cline { 2 - 3 } & $a$ & $-1.5 \times 10^{-10}(1 / \mathrm{sec})$ \\
\hline \multirow{2}{*}{$\begin{array}{c}\text { 弾性係数 } \\
\left(\mathrm{N} / \mathrm{mm}^{2}\right)\end{array}$} & $b$ & $-2.9 \times 10^{-4}$ \\
\cline { 2 - 3 } & $a$ & 1.5 \\
\cline { 2 - 3 } & $c$ & $2.3 \times 10^{4}\left(\mathrm{~N} / \mathrm{mm}^{2}\right)$ \\
\hline
\end{tabular}

各実験結果から，(4)式に示した下地材のバネ剛性 $K$ を算出すると 図 10 となる。図に示すように下地材のバネ剛性は初期材齢 1 週間程 度までは大きく変化するが，その後一定值に収束する特性值が得ら れた。下地材のバネ剛性の算出においては，弾性係数の発現速度が 大きく影響するが，初期材齢における弾性係数の近似関数值の意義 は希薄であり，下地材のバネ剛性を定義することは物理的に困難で ある。そこで，本解析では，下地材のバネ剛性の取り扱いについて は材齢にともない変化せずに一定值で代表し得るものと仮定し, 最 終自由収縮ひずみ, 最終拘束収縮ひずみ, 最終弾性係数から算出さ れる值 $\left(K=1.35 \times 10^{6} \mathrm{kN} / \mathrm{m}\right)$ を解析に用いることとした。 


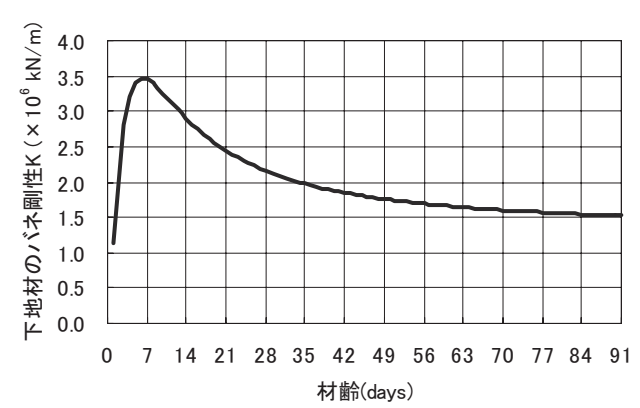

図 10 下地のバネ剛性の変化

また，参考值として，本実験に用いたモルタルの割裂引張試験か ら得られた材齢に対する割裂引張強度（3 体平均值）の変化を図 11 に示す。材齢 91 日で, 強度が低下しており, このようなデータのば らつきが見られるものの, 弾性係数と同様に概㸚材齢 28 日で最終的 な引張強度が発現していることがわかる。

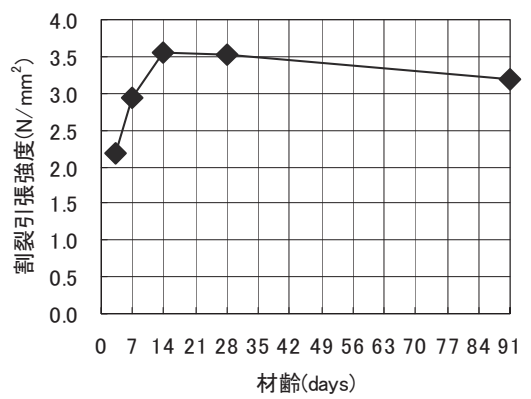

図 11 モルタルの割裂引張強度

\section{2 基礎的実験値との比較による解析精度の確認}

\subsection{1 収縮に伴う変位の比較}

モルタルの材齢にともなう弾性係数, 自由収縮ひずみの変化に対 する本解析モデルの基礎的な特性を確認するために，モルタルの拘 束収縮ひずみを計測した際の試験体モデルを用いて，下地材のバネ 剛性の特性確認を行う。解析は, 図 12 に示寸ようなモルタル仕上げ 面に対し, 要素分割数 400 とした解析モデルを作成し, 91 日間 (2184 時間）の時間変化に対する乾燥収縮解析を行った。
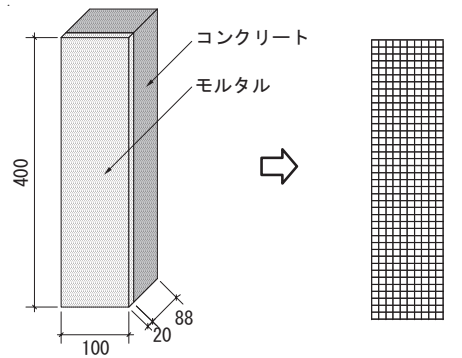

節点数 451

要素数 400

普通モルタル

板厚 $20 \mathrm{~mm}$

ポアソン比 0.2

図 12 基本解析モデル

解析における増分時間間隔 $\Delta t$ は，予備解析によって定めた十分小 さな值 ( $\Delta t=6$ 時間) とした。そして, 左官モルタルの叙り厚を $20 \mathrm{~mm}$ とした平面応力問題を解いた。このとき,ポアソン比は 0.2 とした。 なお, 本解析における拘束節点は, 全節点であり, その拘束節点と 各要素とは，バネ要素で連結されている解析モデルである。
図 13にモルタル仕上げ層長手方向の収縮変位における実験值と 解析值の比較を示す。本解析法は初期材齢においては, 概水実験值 と同様の傾向を示寸ことが確認されたが，最終的な変位量が解析の 方が小さめになる傾向にある結果となった。これらの違いが生じた 原因としては，実際の試験体における下地材のコンクリートの弾性 変形の影響やモルタルの弾性係数の発現に対する特性值の相違及び モルタルの自由収縮特性と拘束収縮特性の計測環境の違いや下地材 のバネ剛性の定義方法等の複合的な要因が考えられる。

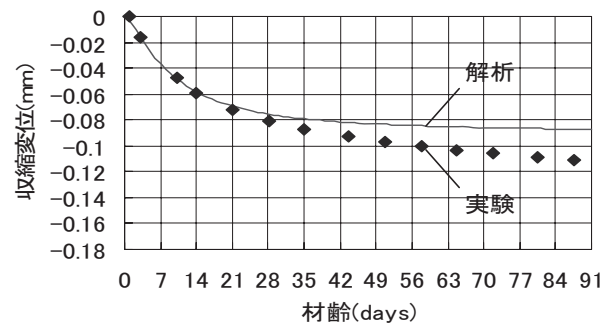

図 13 収縮変位の比較

\subsection{2 要素分割数の影響}

本解析法における要素分割数の影響を調査寸るために, 図 14に示 すような, 要素分割数のことなる解析モデルを用いて, 要素分割数 に対する解の収束特性を調查する。図 15は, 最も要素分割の細かい 要素分割数 400 としたモデルの収縮変位を規準としたときの他の要 素分割数モデルの収縮変位の相対比率を示す。図より, 要素分割数 が 4，16，64，256 と増えていくのに従い, 良好に解が収束していく ことが確認された。

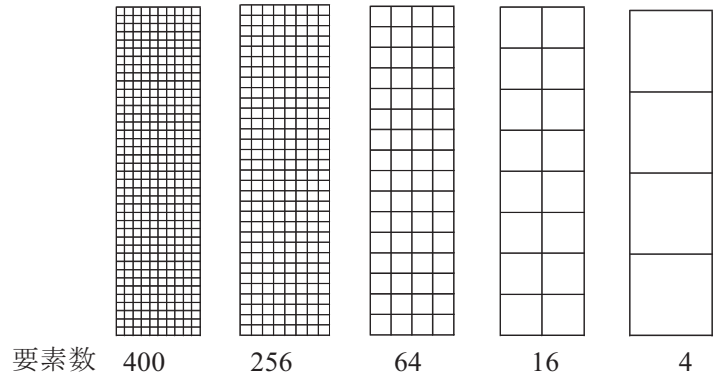

図 14 要素分割数

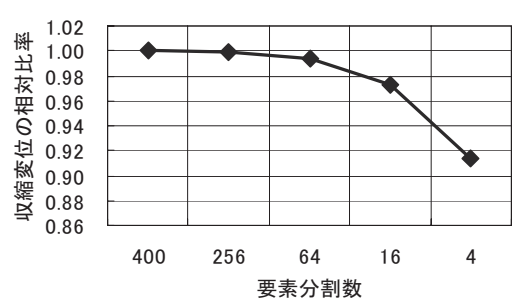

図 15 収縮変位の相対比率

\subsection{3 模擬試験体の解析結果}

本解析法の解析精度を面的な広がりのあるモデルにおいて検証す るために, 3.2 節で示した開口部周辺を模擬した試験体（図 6参照） を図 16に示すような要素数 800 のモデルによって解析した。 


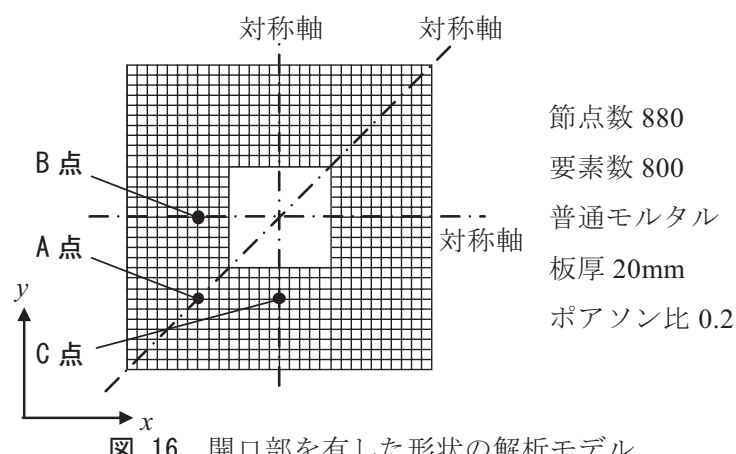

図 17〜図 22に A〜C 点におけるひずみ計測の実験結果と解析結 果を示す。図 17および図 18に示すように，A 点の $x$ 方向ひずみ及 び $y$ 方向ひずみの間には，実験結果には約 $20 \mu$ 差が生じたが，ほ ぼ同程度の值であった。これは，計測箇所の対称性からも予測され た結果であり，良好な計測結果と言える。若干の違いが生じた要因 としては，計測箇所の平滑性や，ひずみゲージを貼る際の施工誤差 などが挙げられる。また, $\mathrm{B}$ 点と $\mathrm{C}$ 点は, 試験体の対角線に対して 対称位置であり, 同一の方向成分同士を比較(図 19 と図 22を比較, 及び図 20 と図 21を比較）すると，B 点および C 点におけるひずみ の傾向が同一であることが確認され，収縮は対称性を伴い各方向に 対し均一に生じていることが示された。また， B 点における $y$ 方向 ひずみ（図 20）抽で $\mathrm{C}$ 点における $x$ 方向ひずみ（図 21）の值は 共に, 実験值が解析值よりも大きな収縮ひずみを示寸結果となった ものの，解析值と実験值は概ね対応していることが確認された。

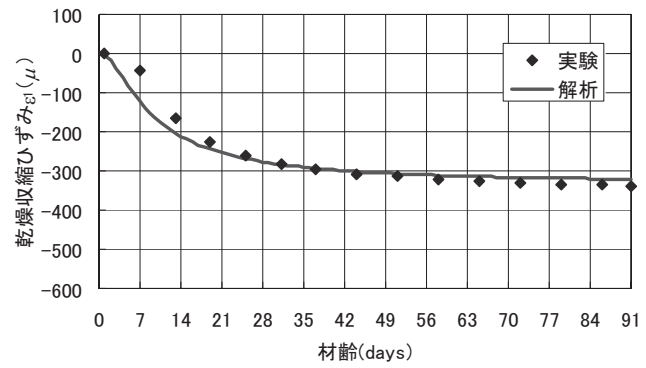

図 $17 \mathrm{~A}$ 点における $x$ 方向ひずみ

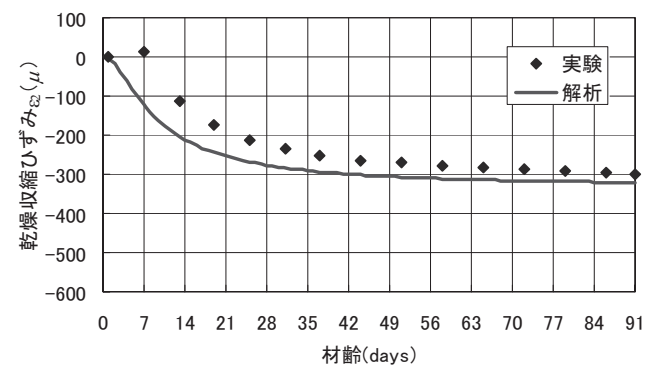

図 18 A 点における $y$ 方向ひずみ

なお，実験におけるひずみの計測データにおいては，計測開始直 後に緩やかに膨張を示しているものもあるが，このような膨張のデ ータが計測された要因としては, モルタル施工後 1 日目の段階で試
験体にひずみゲージを貼り付けたため, モルタルの水分の影響をひ ずみゲージが受けたためなどの, 計測方法における要因が考えられ る。

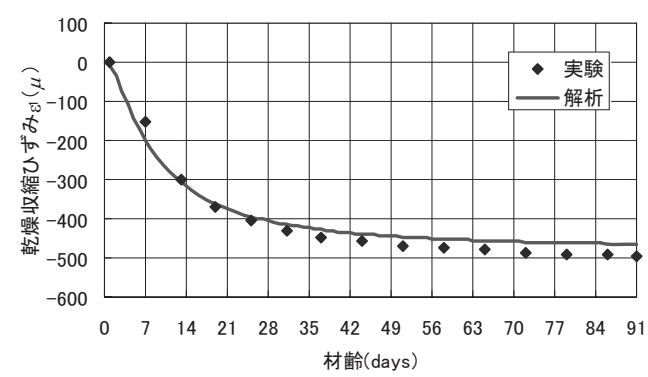

図 19 B 点における $x$ 方向ひずみ

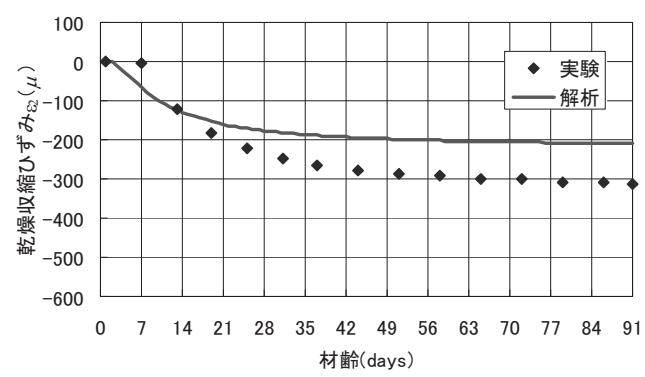

図 20 B 点における $y$ 方向ひずみ

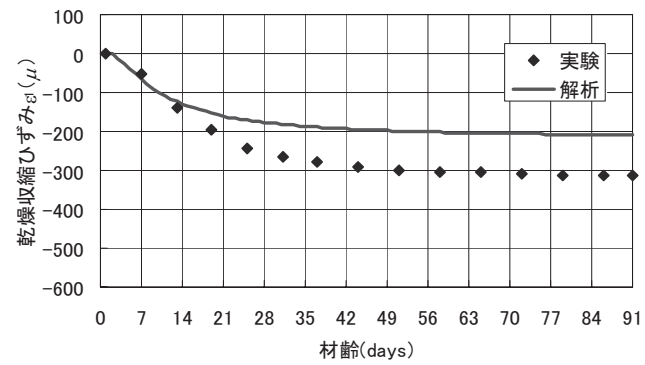

図 $21 \mathrm{C}$ 点における $x$ 方向ひずみ

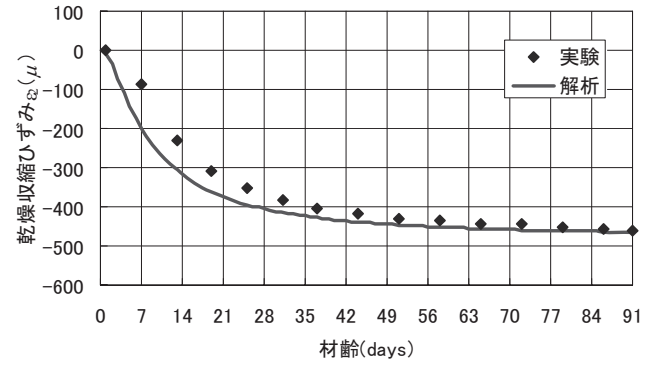

図 $22 \mathrm{C}$ 点における $y$ 方向ひずみ

本実験は，試験体の対称性を考慮し，主ひずみの発生方向が予測 可能な点でのひずみ計測を行っている。そこで，実験で得られた 3 軸成分のひずみデータ $\varepsilon_{1}, \varepsilon_{2}, \varepsilon_{3}$ をもとに，第 1 軸のひずみゲージ $\varepsilon_{1}$ の方向から主ひずみ方向までの角度を求めた結果を図 23〜図 25に 
示す。同図より, A 点における主ひずみの方向は, 解析值（正解值） の $45^{\circ}$ に対し, 実験值は約 $25^{\circ}$ の方向となり, 正解值と異なる結果 となり，3 軸ひずみゲージによる主ひずみの精密な計測が困難であ ること示寸結果となった。しかし, B 点, C 点においては, 初期材 齢では正解值の $0^{\circ}$ と異なるものの, その後正解值に収束する結果 となった。以上の結果より, 実験值と解析值の完全な一致は見られ ないものの, 本解析は, 試験体の対称性を考慮すると, 理論上妥当 な結果が得られていると言える。

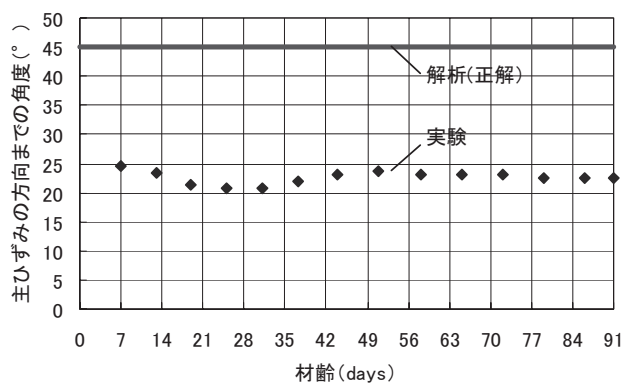

図 23 A 点における主ひずみの方向までの角度

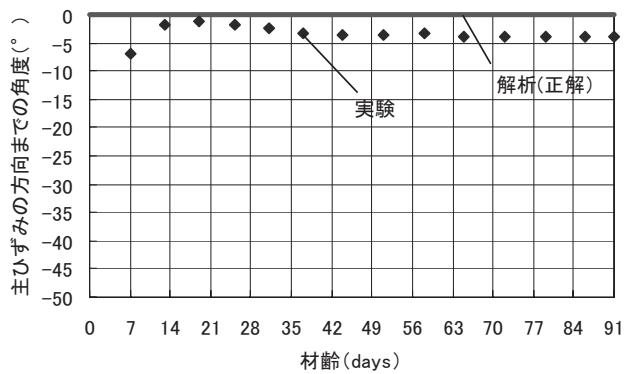

図 24 B 点における主ひずみの方向までの角度

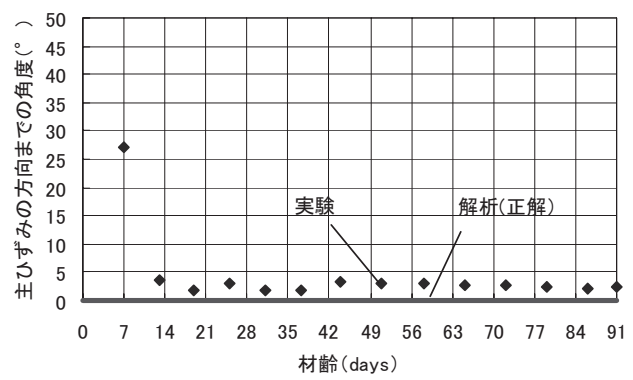

図 25 C 点における主ひずみの方向までの角度

図 26は解析によって得られた主応力図を示し,す心゙ての箇所で引 張方向の主応力が生じる結果となった。図より開口部の入隅部付近 を中心に大きな引張方向の主応力が発生していることがわかる。

また, 解析における 14 日経過時と 91 日経過時の $x$ 方向成分の応 力 $\sigma_{x}$ の分布図（応カコンタ図）を図 27 に示す。図中の数字は， $\sigma_{x}$ の応力值（プラスが引張，マイナスが圧縮）を示しており, 寸べて の位置で引張応力となった。図より，開口部周辺から離れた位置に おける応力の変化は比較的緩やかであるのに対し, 開口入隅部周辺 では，変化が大きいことが分かる。

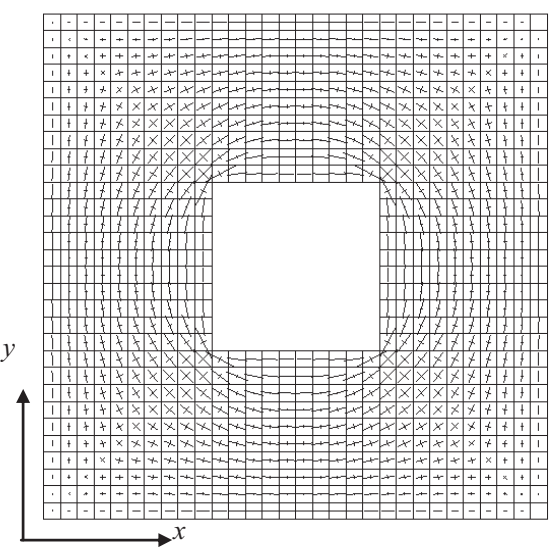

図 26 主応力図（91 日経過時点）

実際に実験に用いた試験体におけるひび割れの発生状沉（91日経 過時点）については，開口入隅部の極近傍においてのみ，微細なひ び割れが生じるのみであり，そこからひび割れが広範囲に渡って進 展することは確認されなかった。このことは, 図 27 に示した応力分 布が，入隅部近傍のみに局所的に生じていることと類似する結果で ある。これらの結果は, 本解析法でひび割れの発生の程度を予測す る場合には，単に発生する応力の大きさだけでなく，応力分布の広 がりも合わせて検討することが重要であることを示唆している。そ こで，次節では，実大のスケールに基づく乾燥収縮応力分布のモデ ル解析を行い, 開口部の大きさや位置, 個数などが及ぼす影響につ いて解析的に検討する。
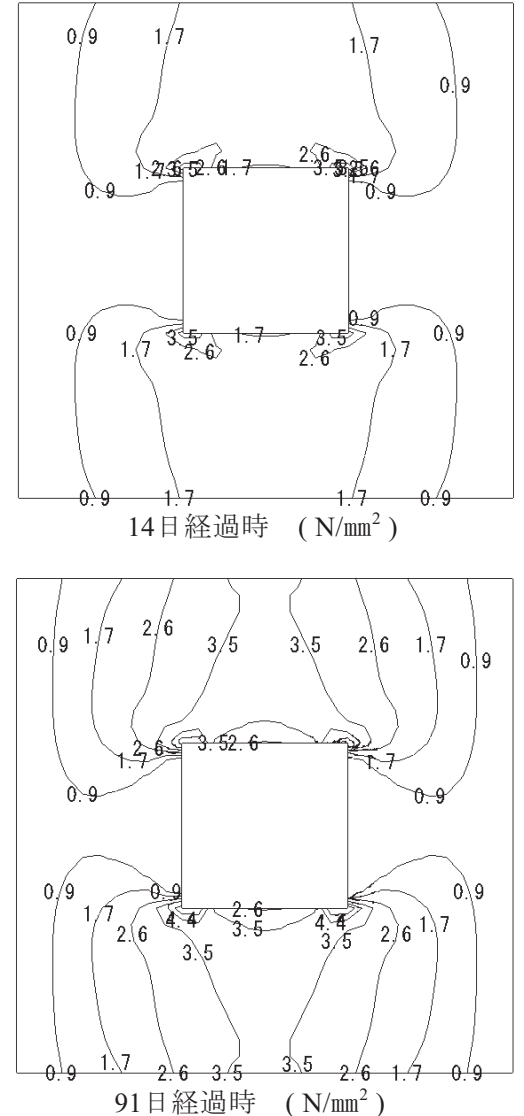

図 27 応力コンタ図 $\left(\sigma_{x}\right.$ 成分 $)$ 


\section{5 解析による各種壁面のひび割れしやすい位置の分析}

\section{1) 開口部形状の影響}

標準的な壁面の解析例として, 図 28に示すような, 高さ $4000 \mathrm{~mm} \times$ 幅 7200mm の壁面モデルを用いて, 開口部の形状，位置および開口 部の個数が，仕上モルタル層の応力分布に与える影響を検討する。 モルタルは，普通モルタル（塗り厚 $20 \mathrm{~mm}$ ）とし，前述の実験結果 と同一のデータとした。図中(a)に示す無開口のモデルを基準に，面 積のことなる開口を有するモデル(b)-(e)，開口部の位置を変えたモ デル(f), 開口の数を変えたモデル $(\mathrm{g}),(\mathrm{h})$ について解析を行った。こ のとき解析における要素分割は，図中に示寸通りである。

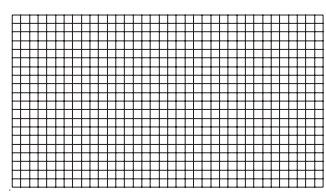

(a) 無開口

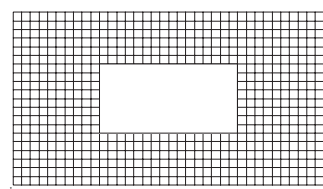

(c) 開口中

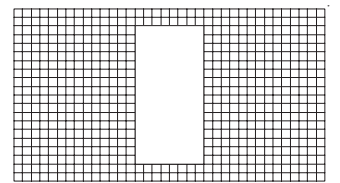

(e) 長開口

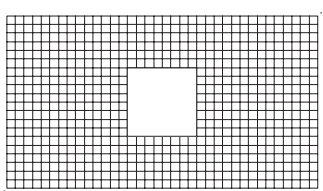

(b) 開口小

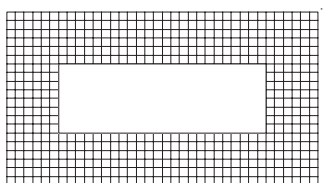

(d) 開口大

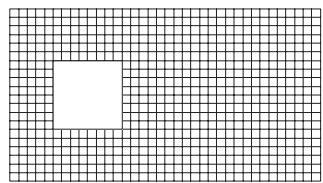

(f) 開口 1

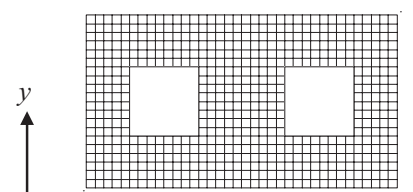

(g) 開口 2

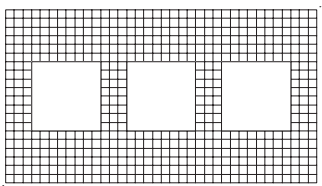

(h) 開口 3
図 28 開口部の異なる解析モデル

図 29に応力コンタ図（ $\sigma_{x}$ 成分：91 日経過時）を示す。図中の丸 で囲んだ領域に大きな引張力応力が生じており，これらの位置にお いてひび割れが発生することが予測される。これらの結果より，以 下のことが考察される。

1）開口面積の大小に関わらず，開口入隅部には，局所的に大きな 引張応力が生じる。

2）開口面積が大きくなると，開口部によって細くさえぎられた部 分に大きな水平方向（ $x$ 方向）の引張応力が生じる傾向にある。

3）開口の数が変化した場合は, 開口部周辺の応力分布は複雑に変 化する。

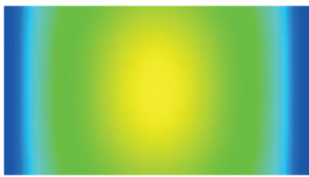

(a) 無開口

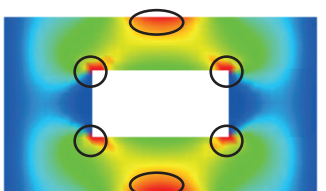

(c) 開口中

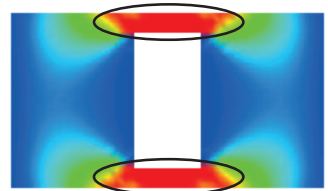

(e) 長開口

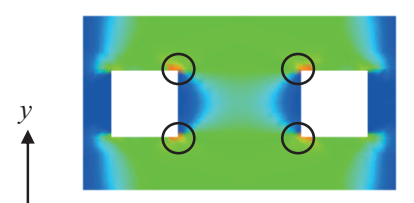

(g) 開口 2

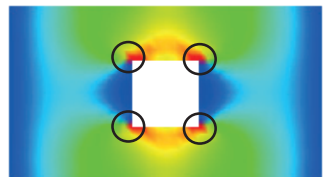

(b) 開口小

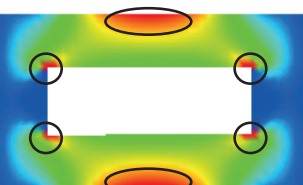

(d) 開口大

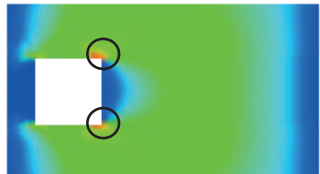

(f) 開口 1

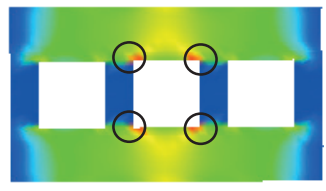

(h) 開口 3

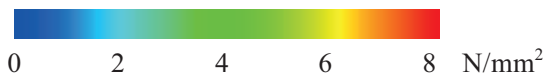

図 29 応力コンタ図（ $\sigma_{x}$ 成分：91 日経過時）

\section{2)伸縮調整目地の効果に関するモデル解析}

伸縮調整目地の影響を検討するために,前節に示した開口大モデ ル(d)において，開口部に沿って目地のある場合の解析を行った。目 地のモデル化の方法は, 目地部でそれぞれ要素を分割し, 別の解析 モデルとして扱うことで，モルタル層の不連続性を評価し，個別に 計算した各応力の結果を結合することで, 図 30 に示す応力コンタ図 を作成した。

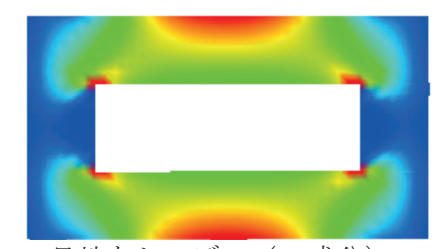

目地なしモデル（ $\sigma_{x}$ 成分）

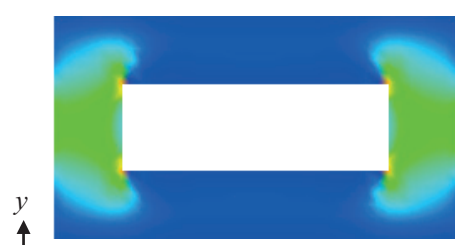

目地なしモデル（ $\sigma_{y}$ 成分）

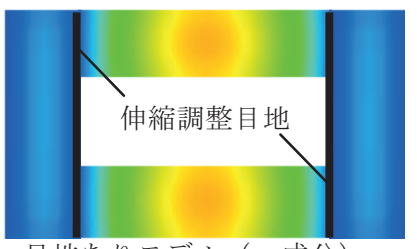

目地ありモデル（ $\sigma_{x}$ 成分）

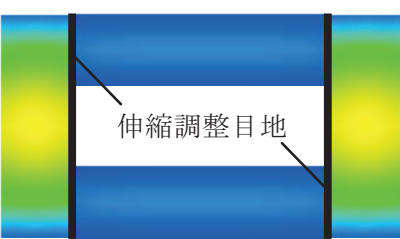

目地ありモデル（ $\sigma_{y}$ 成分）

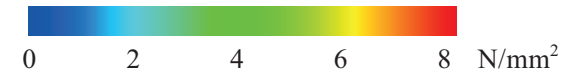

図 30 応力コンタ図 (91 日経過時)

図 30 の左側が目地なしのモデル, 右側が目地ありのモデルであり， 
それぞれ $x$ 方向および $y$ 方向の応力 (91 日経過時) の分布を示して いる。図に示寸ように，伸縮調整目地がある場合には，開口部コー ナーなどに大きな引張応力が生じているものの, 目地を入れること で, 応力分布が変化し, 応力が分散して生じていることが分かる。 また, 本解析結果は, 幅広開口部における伸縮調整目地は $x$ 方向 (水 平方向）については，開口部四隅の応力を低減できるが，開口中央 部の上下の壁には大きな応力が生じ，この位置のひび割れ対策が必 要となることを示している。同様に, 同図 $y$ 方向(鉛直方向)に関し ては, 開口部両脇の壁面中央部の応力がむしろ大きくなり, 設計や 施工上の配慮が必要となることを示唆している。

\section{5. まとめ}

本論文では，仕上モルタルの乾燥収縮を下地コンクリートが拘束 することでモルタル内部に生じる応力を解析する手法として, 下地 材の拘束力としてバネ剛性を用いた解析を行った。モルタルの材料 特性を示寸各種定数については, 提案した実験法によって得られた データを用いた。

本解析法により，開口部を模した口の字形の試験体を用いて，2 次元問題における解析法の検証を行なった結果，概ね実験結果と良 好な対応が確認され，本解析法の有効性を検証した。ただし，これ らの検証を行った実験は恒温恒湿（温度 $20^{\circ} \mathrm{C}$, 湿度 $60 \% \mathrm{Rh}$ ）の環境 条件下で養生，計測をした結果であることを付け加える。またこれ らの基礎実験に基づくデータから実大スケールのパターン解析を行 い, 開口部を有する壁面に生じる収縮応力の特性を解析的に検討し た。伸縮調整目地を考慮したモデル解析を行った結果, 目地を入れ ることで，大きな引張応力の生じる領域を分散することが可能なこ とを数值計算によって示した。

本研究では壁面を構成する左官モルタルにおけるひび割れの発生 しやすい位置を求めることを主眼としているため, クリープや応力
緩和については論じていない。ただし，本解析におけるバネ剛性は 下地に拘束された状態の左官モルタルから求められているため, 厳 密には，これらを無視しているわけではない。ひび割れが発生する か否かの判定にはこれらの影響を考慮することが不可欠と認識して おり，ひび割れの発生予測に関する検討を行う際には, クリープや 応力緩和の影響を考慮する予定である。また，今後，実験により， モルタル厚みごとの変形入力データを整備することが本解析手法の 有効性を高めるものと認識している。

\section{謝辞}

本研究には坂下明氏（鹿島建設（株）当時広島大学大学院生）の 協力を得た。また, 本研究の一部は文科省科研費（基盤 B 19360250） の助成を受けた。末筆ながら謝意を表す。

\section{参考文献}

1) 日本建築学会発行: 鉄筋コンクリート造建築物の収縮ひび割れ制御・設計施工 指針 (案) ・同解説, 2006.2

2) 青木優介, 下村匠, 丸山久一: 乾燥収縮応力解析に基づくコンクリート部材のひ び割れ予測に関する研究, コンクリート工学年次論文報告集, Vol.20, No.2, pp.643-648 1998.6

3) 前田孝一: 弾性支持盤上の梁モデルを利用した仕上材料のひび割れ, 及び, 剥 離現象の解析的研究, 日本建築学会構造系論文集, 第 473 号, pp.57-65, 1995.7

4) 椿龍哉, 堀江克幸: 環境条件の変化を考慮したコンクリートの乾燥収縮のモデル 化, コンクリート工学年次論文報告集, Vol.20, No.2, pp.625-630,1998.6

5) 小澤泰士, 斉藤成彦, 檜貝勇: 3 次元剛体バネモデルによるコンクリートの収縮ひ び割れ解析, コンクリート工学年次論文集, Vol.26, No.1, pp.477-482, 2004.

6) O.C.ツィエンキーヴィッツ著: マトリックス有限要素法, 培風館, 1984.9

7) 根本かおり, 眞方山美穂, 大久保孝昭, 松本慎也: コンクリートと左官モルタルの 接着一体性に及ぼす初期養生環境の影響, 日本建築学会構造系論文集, 第 613 号, pp.7-14, 2007.3

（2009年 6 月26日原稿受理，2009年11月13日採用決定） 